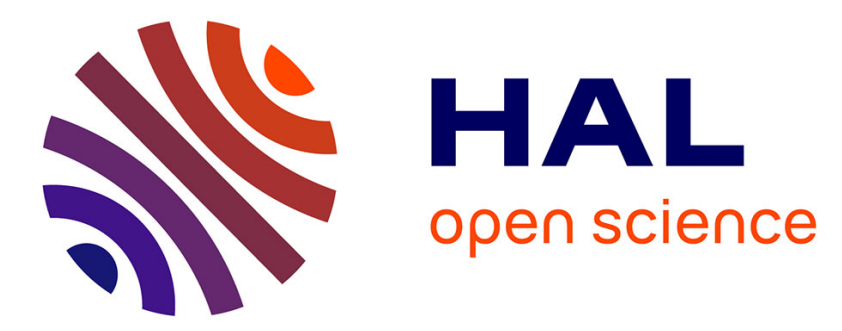

\title{
Light absorption and hole-transport properties of copper corroles: from aggregates to a liquid crystal mesophase
} Di Gao, Judicaelle Andeme Edzang, Abdou Karim Diallo, Thibault Dutronc, Teodor Silviu Balaban, Christine Videlot-Ackermann, Emmanuel Terazzi, Gabriel Canard

\section{To cite this version:}

Di Gao, Judicaelle Andeme Edzang, Abdou Karim Diallo, Thibault Dutronc, Teodor Silviu Balaban, et al.. Light absorption and hole-transport properties of copper corroles: from aggregates to a liquid crystal mesophase. New Journal of Chemistry, 2015, 39 (9), pp.7140-7146. 10.1039/C5NJ01268F . hal-01785392

\section{HAL Id: hal-01785392 \\ https://hal.science/hal-01785392}

Submitted on 4 May 2018

HAL is a multi-disciplinary open access archive for the deposit and dissemination of scientific research documents, whether they are published or not. The documents may come from teaching and research institutions in France or abroad, or from public or private research centers.
L'archive ouverte pluridisciplinaire HAL, est destinée au dépôt et à la diffusion de documents scientifiques de niveau recherche, publiés ou non, émanant des établissements d'enseignement et de recherche français ou étrangers, des laboratoires publics ou privés. 


\title{
Light absorption and hole-transport properties of copper corroles: from aggregates to a liquid crystal mesophase.
}

\author{
Di Gao, ${ }^{a}$ Judicaelle Andeme Edzang, ${ }^{b}$ Abdou Karim Diallo, ${ }^{b}$ Thibault \\ Dutronc, ${ }^{c}$ Teodor Silviu Balaban, ${ }^{a}$ Christine Videlot-Ackermann, ${ }^{* b}$ Emmanuel \\ Terazzi*c $^{\star c}$ and Gabriel Canard ${ }^{* b}$
}

\begin{abstract}
The synthesis of the corrole-based liquid crystal phase CorLC is described together with its full characterization by a combination of Polarised Optical Microscopy (POM), ThermoGravimetric Analysis (TGA), Differential Scanning Calorimetry (DSC) measurements and Small-Angle X-Ray Diffraction (SA-XRD) which shows that CorLC has an hexagonal columnar organization at room temperature. The light absorption and hole-transport properties of the mesophase CorLC is compared with the ones featured by assemblies of its parent meso triaryl (Cor1) and per-aryl (Cor2) derivatives. J-Aggregates are changed into $\mathrm{H}$-aggregates when the intermolecular distance is increasing with the peripheral steric hindrance producing lower holetransport properties.
\end{abstract}

\section{Introduction}

The highly versatile optical, electronic and photophysical properties of porphyrin and phthalocyanine derivatives has led to their large application in the fields of organic electronics and optoelectronics. ${ }^{1}$ In this regard, their ability to produce large assemblies or aggregates is particularly employed to construct organized and high light-absorbing materials displaying efficient charge and/or exciton transport properties that are essential in the preparation of organic solar cells ${ }^{2}$ or photoconductors. ${ }^{3}$ Among the different supramolecular tools that are used to build self-organized porphyrin and phthalocyanine systems, their incorporation in liquid crystal (LC) phases ${ }^{4}$ is attractive since the morphology and orientation of LC thin films can be controlled to obtain large area and defect free devices. ${ }^{5}$ For example, an exciton diffusion length longer than $12 \mathrm{~nm}$ has been measured in a nematically organized porphyrin layer ${ }^{6}$ while a field-effect mobility of 0.7 $\mathrm{cm}^{2} \mathrm{~V}^{-1} \mathrm{~s}^{-1}$ was exhibited by an Organic Field Effect Transistor (OFET) incorporating a liquid crystalline copper phthalocyanine.

Corrole and its metal complexes are currently attractive members of the porphyrinoid family since their syntheses $^{8}$ and functionalizations ${ }^{9}$ have been extensively developed during the last fifteen years and are thus amenable to gram-scale synthesis, sometimes essential for developing devices. Consequently, corrole derivatives are employed in many research areas including catalysis, ${ }^{10}$ sensors $^{11}$ or medicine. $^{12}$ Nevertheless, very few reports concern the preparation and characterization of large corrole-based assemblies $^{13}$ and their incorporation into electronic devices. ${ }^{14}$ We report here the synthesis and full characterization of a copper corrole-based liquid crystal mesophase CorLC (Scheme 1). Its supramolecular organization was studied by UV/Visible spectroscopy and was compared to the ones produced by aggregates of its parent meso triaryl (Cor1) and per-aryl (Cor2) derivatives (Scheme 1). The hole-transport properties of these three compounds were additionally measured through their incorporation in OFETs.

\section{Results and discussion}

\section{Synthesis of the mesogen CorLC.}

The liquid crystal CorLC was prepared in four synthetic steps starting from the copper(III) meso-tris $(p$ methoxyphenyl)corrole Cor1 (Schemes 1 and S1, ESI $\dagger$ ). ${ }^{15}$ The full bromination of $\beta$-positions followed by a Suzuki crosscoupling procedure afforded the per-aryl substituted copper corrole Cor2 as previously reported. ${ }^{16}$ A demethylation using standard conditions afforded the per-aryl complex substituted by eleven $p$-hydroxyphenyl groups in $44 \%$ yield without any noticeable removal of the copper ion. It has to be noted that this latter derivative is enough soluble in sufficiently polar media in order to be purified and characterized. The expected compound CorLC was prepared in a yield of $23 \%$ by the subsequent condensation of an excess of the benzyl chloride derivative 1 in basic conditions. Its purity was confirmed by its ${ }^{1} \mathrm{H}$ NMR spectrum and by its MALDI-TOF spectrum showing only its molecular peaks and the corresponding sodium adduct (ESI $\dagger$ ). We note here that if a reaction has to be performed more than tenfold on the same substrate, without allosteric effects, it is remarkable that the overall yield is in the two digit region. 


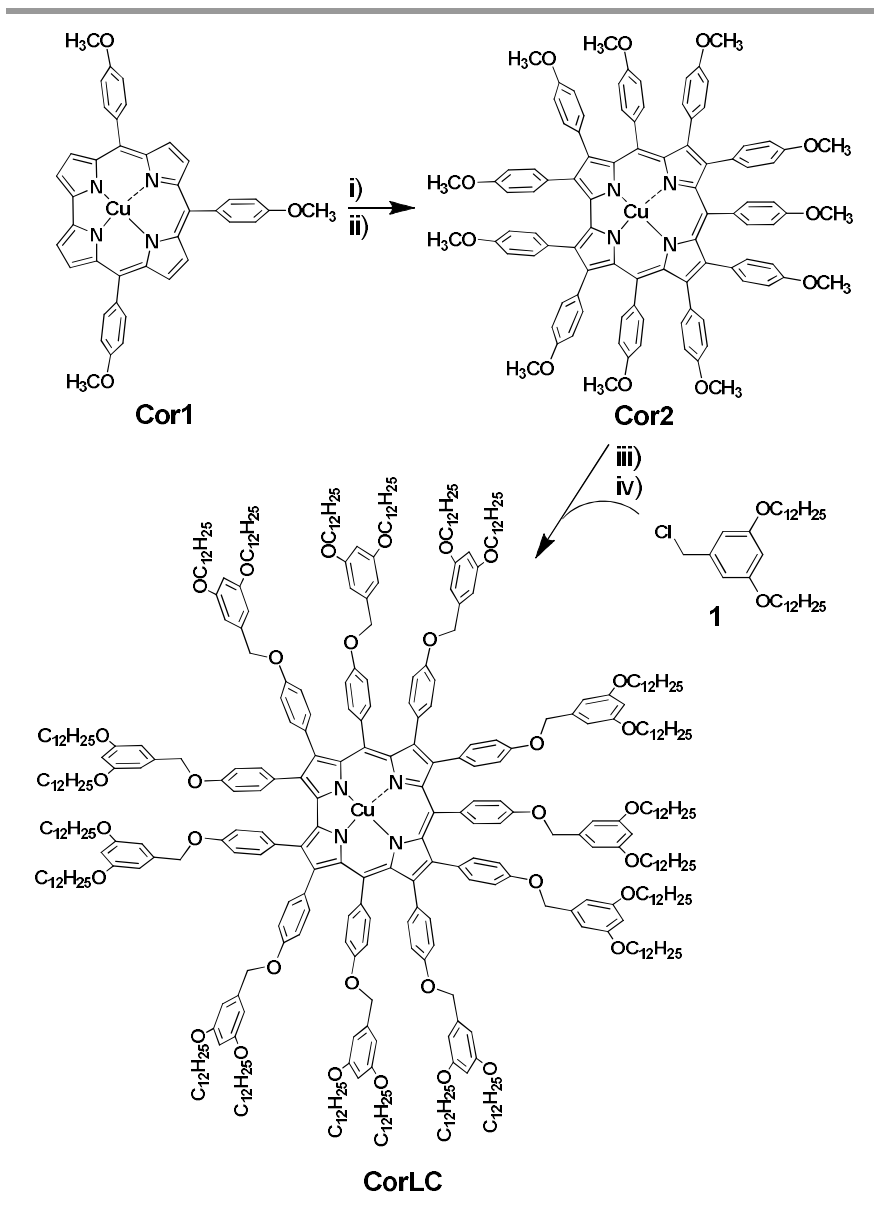

Scheme 1 Synthesis of the liquid crystal corrole CorLC. i) a) $\mathrm{Br}_{2}$, pyridine, $\mathrm{CHCl}_{3}$; b) $\mathrm{NaS}_{2} \mathrm{O}_{5}, \mathrm{H}_{2} \mathrm{O}(45 \%)$. ii) $\mathrm{Pd}_{2}(\mathrm{dba})_{3}$, $\mathrm{K}_{2} \mathrm{CO}_{3}, \quad p-\mathrm{H}_{3} \mathrm{CO}-\mathrm{C}_{6} \mathrm{H}_{4}-\mathrm{B}(\mathrm{OH})_{2}$, toluene (71\%). iii) $\mathrm{BBr}_{3}$, $\mathrm{CH}_{2} \mathrm{Cl}_{2}$ (44\%). iv) $\mathrm{K}_{2} \mathrm{CO}_{3}$, DMF (23\%).

\section{Thermal behaviour of CorLC.}

The thermal behavior of CorLC was studied by a combination of Polarised Optical Microscopy (POM), ThermoGravimetric Analysis (TGA), Differential Scanning Calorimetry (DSC) measurements and Small-Angle X-Ray Diffraction (SA-XRD) (Fig. 1, Fig. S1, S2 and S3, ESI $\dagger$ ). The TGA measurement indicates that the compound is stable up to $300{ }^{\circ} \mathrm{C}$ (Fig. S1, ESI $\uparrow$ ). Temperature dependent POM observations showed a fluid and birefringent texture that is typical of the occurrence of a liquid-crystalline organization. This texture does not show any significant changes until the isotropisation occuring at $103{ }^{\circ} \mathrm{C}$ i.e. a transition from the liquid crystalline phase to the standard liquid state (I). Upon cooling, this phase transition is reversible and occurs at $95{ }^{\circ} \mathrm{C}$ (i.e. with a small hysteresis). Notably, the liquid crystal phase remains birefringent and fluid at room temperature. Cooling down the isotropic liquid sample at very low speed $\left(0.1{ }^{\circ} \mathrm{C} \cdot \mathrm{min}^{-1}\right)$ forms the liquid crystalline phase characterized by a fan texture that strongly suggests that the compound self-organizes in a columnar hexagonal $\left(\mathrm{Col}_{h}\right)$ liquid crystalline phase (Fig. 1a). This preliminary result was confirmed by DSC (Fig. 1b). The solid complex CorLC was transformed to the $\mathrm{Col}_{\mathrm{h}}$ mesophase through a broad first order transition $\left(-30{ }^{\circ} \mathrm{C}, \Delta \mathrm{H}=80.4 \mathrm{~kJ} \cdot \mathrm{mol}^{-1}, \Delta \mathrm{S}=330.5 \mathrm{~J} \cdot \mathrm{mol}^{-1} \cdot \mathrm{K}^{-1}\right)$ that preceded a second first order transition $\left(103.4{ }^{\circ} \mathrm{C}, \Delta \mathrm{H}=\right.$
$22.1 \mathrm{~kJ} \cdot \mathrm{mol}^{-1}, \Delta \mathrm{S}=58.8 \mathrm{~J} \cdot \mathrm{mol}^{-1} \cdot \mathrm{K}^{-1}$ ) of the $\mathrm{Col}_{\mathrm{h}}$ phase into the liquid isotropic state I.

a)
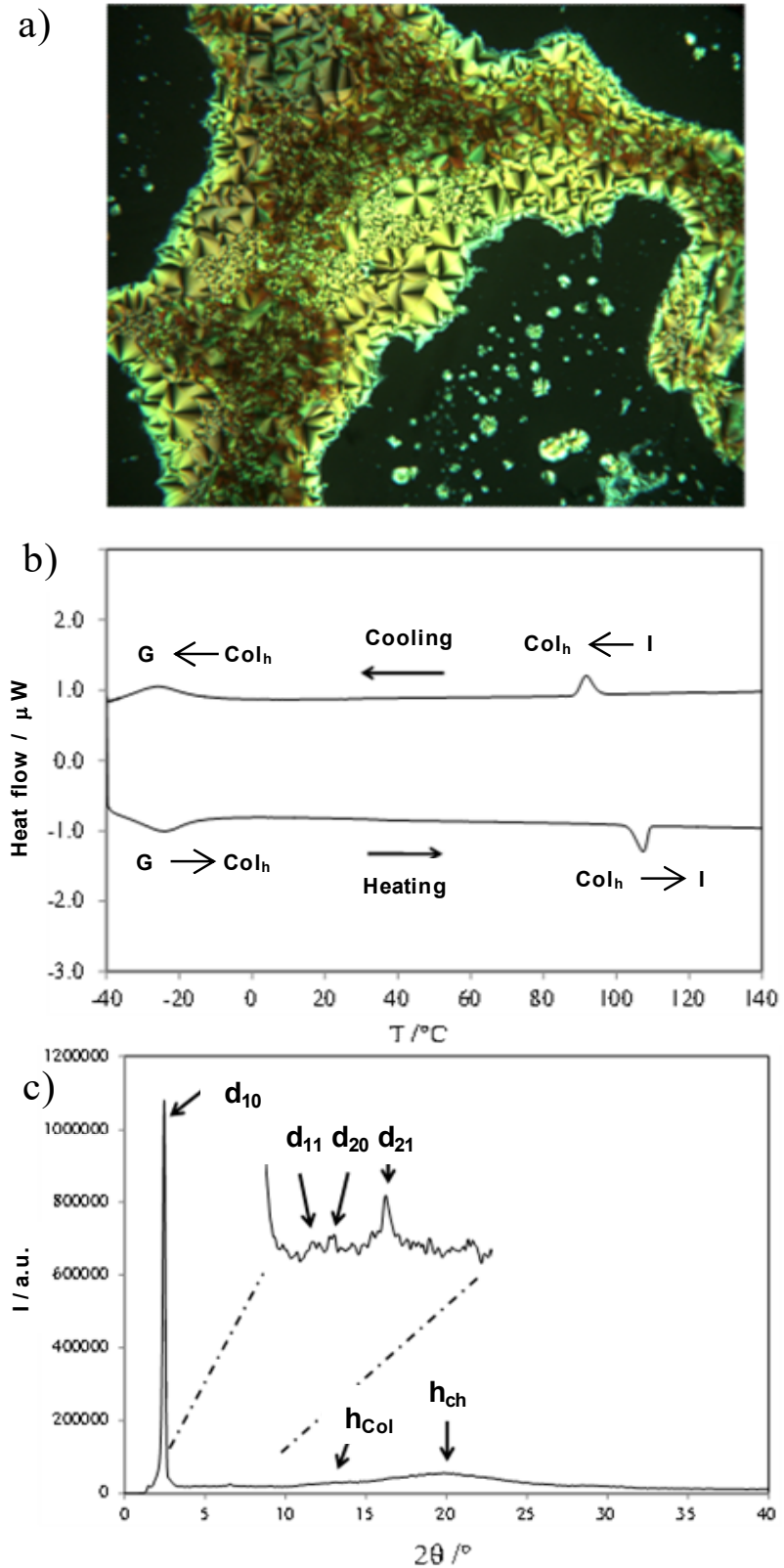

Fig. 1 (a) Optical texture observed by the POM of CorLC in the $\mathrm{Col}_{\mathrm{h}}$ mesophase at $90{ }^{\circ} \mathrm{C}$ after cooling from the isotropic liquid. (b) DSC trace of CorLC recorded at $5{ }^{\circ} \mathrm{C} / \mathrm{min}$ (second heating and cooling). (c) SA-XRD profile in the liquid crystalline phase and associated indexation of CorLC at $30{ }^{\circ} \mathrm{C}$.

\section{Structure of the CorLC mesophase.}

Temperature-dependent SA-XRD patterns of CorLC were recorded in the $20-140{ }^{\circ} \mathrm{C}$ temperature range. The presence of a large and diffuse signal at approximately $4.5 \AA\left(\mathrm{h}_{\mathrm{ch}}\right)$, which was associated with the liquid-like molten chains confirmed the fluid-like nature of the mesophase. Short acquisition times (i.e. 
10 min per scan) allowed to detect a very weakly temperaturedependent sharp and intense signal at low angle in the 20-100 ${ }^{\circ} \mathrm{C}$ temperature range. A longer acquisition time at $30{ }^{\circ} \mathrm{C}$ (i.e. 24 hours) revealed the presence of three additional very weak reflections in the low angle region (Fig. 1c)). These four sharp reflections were indexed as $(h k)=(10),(11),(20)$, (21) (squared spacing ratios $h^{2}+k^{2}+h k=1,3,4$, 7; see Fig. S2, ESI $\dagger$ ) confirming the formation of a $\mathrm{Col}_{\mathrm{h}}$ arrangement suggested by the POM observation (plane group $p 6$ or $p 6 \mathrm{~mm}$ ). ${ }^{17}$ A unit cell parameter of $a=41.1 \AA$ and a cross-sectional area of $S=1462 \AA^{2}$ were thus deduced from this last measurement. The pattern recorded at $30{ }^{\circ} \mathrm{C}$ shows a second broad reflection $\left(\mathrm{h}_{\mathrm{Col}}\right)$ located at about $7 \AA$ partially overlapping the first one corresponding to the molten aliphatic chains (i.e. $\mathrm{h}_{\mathrm{ch}}$ ). The separation of these two broad signals by fitting them with Gaussian functions (Fig. S3, ESI $\dagger$ ) allowed to accurately determine the value of $\mathrm{h}_{\mathrm{Col}}=6.86 \AA$. Making the assumption that $\mathrm{h}_{\mathrm{Coh}}$ corresponds to the separation between the complexes within a column, we thus calculated a volume of $V=S \cdot \mathrm{h}_{\mathrm{Col}}=$ $10029 \AA^{3}$ for an hexagonal columnar unit cell. Taking into account a realistic density of $d=1.0 \mathrm{~g} \cdot \mathrm{cm}^{-3}$ in the mesophase, ${ }^{17 \mathrm{~d}}$ we estimated that the number of complexes CorLC per unit cell $\mathrm{Z}$ amounts to 1 according to equation (1) where $N_{a v}$ is the Avogadro's number, $M M_{m}$ is the molecular weight of the molecule in $\mathrm{g} \cdot \mathrm{mol}^{-1}$, and $V$ is the volume of the unit cell in $\AA^{3}{ }^{17 \mathrm{~d}}$ The liquid crystalline supramolecular organization of complex CorLC should thus be considered as a bidimensional long-ranged network with a rather disorganized third direction (i.e. along the column axis) that is typical of $\mathrm{Col}_{\mathrm{h}}$ organizations. This kind of organization is commonly observed in mesophases produced by porphyrin- and phthalocyanine-based discotic derivatives bearing multiple long alkyl chains. ${ }^{4}$ For example, a $\mathrm{Col}_{\mathrm{h}}$ organization was also displayed by a porphyrin bearing four peripheral mesogenic bis-dodecyloxy aryl groups which are similar to those born by CorLC. ${ }^{4 b}$

(1) $Z=\left(d \cdot N_{A V} \cdot V \cdot 10^{-2}\right) \div M M_{m}=0.94 \sim 1$

\section{Aggregation properties of Cor1, Cor2 and CorLC.}

Copper meso-triarylcorroles are known to show hyper electronic spectra that are strongly sensitive to the nature of the meso-substituents that are involved in phenyl-to- $\mathrm{Cu}\left(d_{x^{2}-y^{2}}\right)$ charge transfers and contribute to the main Soret band peak. ${ }^{18}$ This orbital interaction is due to and increases with the saddling of the macrocycle which is reinforced by the introduction of bulky $\beta$-aryl groups. ${ }^{16,19}$ This effect is here illustrated by the UV/Visible spectra of diluted dichloromethane solutions of Cor1, Cor2 and CorLC (Fig. 2). The per-aryl substitution produces the broadening of the Soret band which is red-shifted from $433 \mathrm{~nm}$ in the spectrum of Cor1 to $463 \mathrm{~nm}$ and $464 \mathrm{~nm}$ in the respective electronic spectra of Cor2 and CorLC. On the other side, the replacement of the methyl groups of Cor2 by benzyl substituents in CorLC does not induce any significant change in the location of the B and Q bands and on the shape of the UV/visible spectrum. This similarity is due to the equivalent electron-donating properties of these two groups and shows that the concomitant introduction of 11 additional aryl groups and 21 peripheral alkyl chains does not produce any supplementary distortion of the aromatic corrole ring.

Thin solid films of Cor1, Cor2 and CorLC were prepared by the slow evaporation of their respective dichloromethane solutions. The formation of aggregates is illustrated by the broadening of the resulting electronic spectra that gives, in addition, insights of the relationship between the corroles substitutions and their supramolecular organizations (Fig. 2).

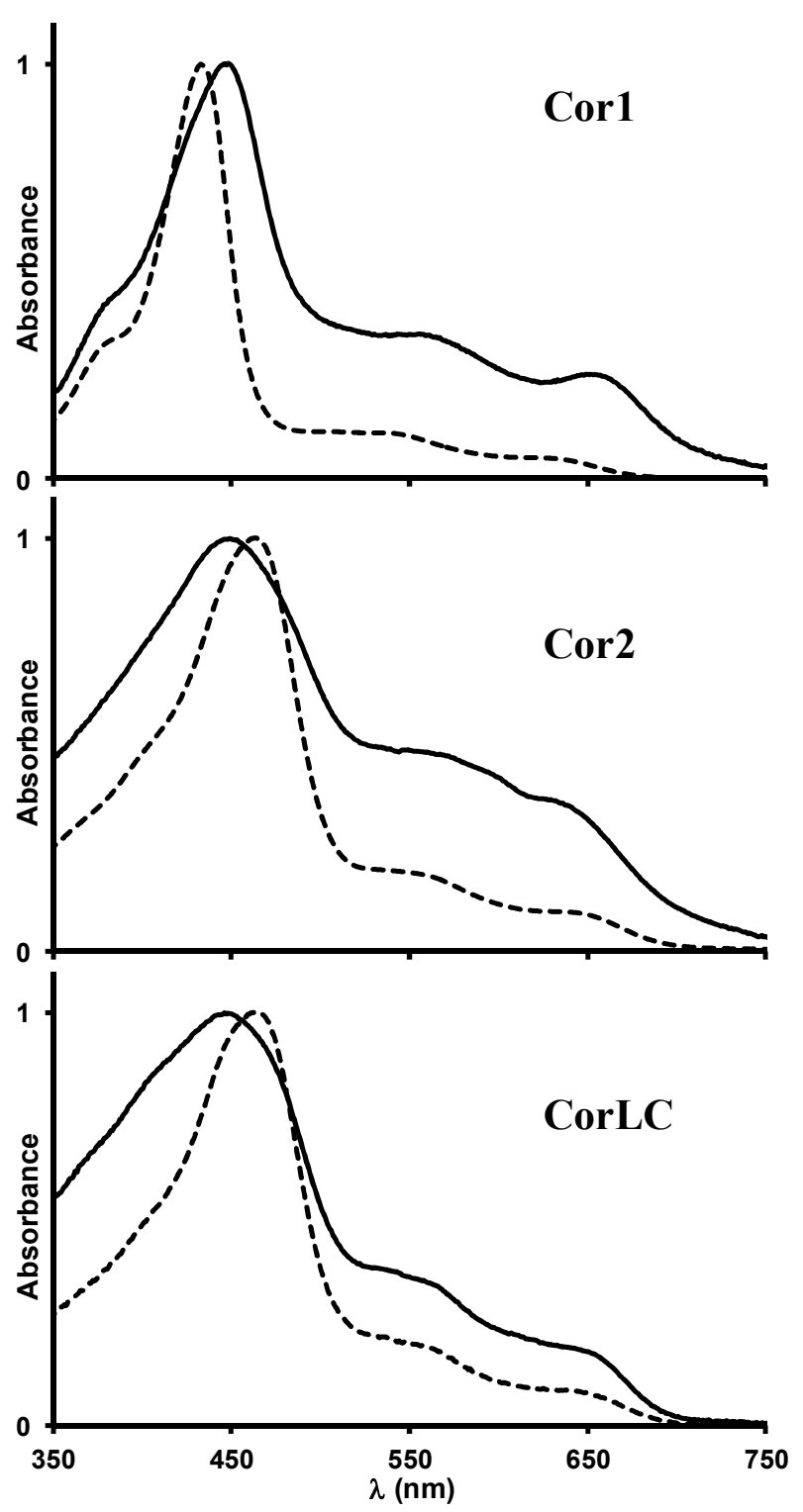

Fig. 2 Normalized UV-Visible absorption of diluted dichloromethane solutions (dashed lines) and thin solid films (solid lines) of Cor1, Cor2 and CorLC.

The band maxima are red-shifted by ca $15 \mathrm{~nm}$ when assemblies of Cor1 are produced because of the probable formation of J- 
aggregates. This supramolecular architecture is commonly observed in the single crystal X-ray structures of copper mesotriarylcorrole derivatives where corrole assemblies are formed thanks to, among others, an intermolecular interaction between the meso-aryl group of one complex with the metallic centre of the adjacent one producing short inter-macrocycle distances. ${ }^{20}$ On the other side, the per-aryl substitution of Cor2 and CorLC induces the formation of $\mathrm{H}$-aggregates as evidenced by the ca $20 \mathrm{~nm}$ blue-shift of their Soret band maxima (Fig. 2). The peripheral sterical hindrance of Cor2 combined with the multiple intermolecular interactions between alkyl chains in the LC phase CorLC, inhibits the direct participation of the copper ion in the supramolecular organization and thereby allows the formation of a different intermolecular packing. The formation of $\mathrm{H}$-assemblies along the column axis is in accordance with the $\mathrm{Col}_{\mathrm{h}}$ organization of the CorLC mesophase (see below).

\section{Hole-transport properties of Cor1 and Cor2.}

To further study the physico-chemical properties of Cor1, Cor 2 and CorLC assemblies, their charge-transport properties were investigated through their incorporation in OFETs. Bottom-gate thin-film transistors with bottom electrode contacts were fabricated to realize so-called BGBC (BottomGate Bottom-Contact) devices. Linear channel lengths $(\mathrm{L}=25$ or $50 \mu \mathrm{m}$ ) were realized by vacuum evaporation of gold through a shadow mask directly on the gate. To complete the device structure, the depositions of the active layers were achieved by drop-casting of dichloromethane solutions (or liquid CorLC) onto the surface of linear BGBC devices. All measurements were performed in air and at room temperature. Even if numerous OFETs were prepared for each derivative, only the two best results obtained among the operating transistors are presented herein.

A field effect transistor activity was observed for Cor1 and Cor2-based assemblies by applying a negative drain and negative gate voltages in order to operate in the accumulation mode. These results demonstrate that Cor1 and Cor2 behave as p-type semiconductors in air as shown by the typical output characteristics of a Cor1-based OFET on $\mathrm{Si} / \mathrm{SiO}_{2}$ substrate under negative and positive voltages (Fig. 3a and Fig. 3b). Under negative gate voltages, the successive increase of the drain current indicates that the BGBC device based on Cor1 operates as an accumulation mode p-channel device (Fig. 3a). The transport of positive carriers is confirmed by the depletion mode under positive voltages (Fig. $3 \mathrm{~b}$ ). In the depletion mode, carriers are driven away from the semiconductor interface, which leads to a decrease of the drain current. The field effect mobility $(\mu)$, threshold voltage $\left(V_{\mathrm{T}}\right)$ and on/off ratio $\left(\mathrm{I}_{\mathrm{on}} / \mathrm{I}_{\text {off }}\right)$ of the most efficient OFETs incorporating Cor1 and Cor2 are summarized in Table 1 (All results are presented in Table S1, ESI $\dagger$ ). The highest field effect mobility in the saturation regime at $V_{D}=-90 \mathrm{~V}$ was extracted for Cor1 and gives a value of $1.36 \times 10^{-6} \mathrm{~cm}^{2} / \mathrm{V} \cdot \mathrm{s}^{-1}$ together with a threshold voltage $V_{\mathrm{T}}$ of $+14.8 \mathrm{~V}$ and an on/off ratio of 24.5. The increasing sterical hindrance of the peripheral substitution of Cor2 probably produces a lower mobility of $1.32 \times 10^{-7} \mathrm{~cm}^{2} / \mathrm{V} . \mathrm{s}^{-1}$ together with a threshold voltage $V_{\mathrm{T}}$ of $+38.5 \mathrm{~V}$ and an on/off ratio of 10 . All devices incorporating CorLC failed to give charge-transport properties. Identical results were obtained when an hydrophobic substrate $\mathrm{Si} / \mathrm{SiO}_{2}$ modified by a grafted self-assembly monolayer of long alkyl chains was used to induce the homeotropic alignment of the CorLC discotic molecules. ${ }^{21}$ Although thin films were cast as such, or with an annealing step, these failed to improve the microstructural order for achieving more efficient charge transport properties in Cor1, Cor2 and CorLC thin films. However, these functional transistors are the first examples of OFETs using corrole derivatives as active layers and the variation of their low efficiencies are still illustrating the impact of the peripheral substitution on the corroles supramolecular organization.

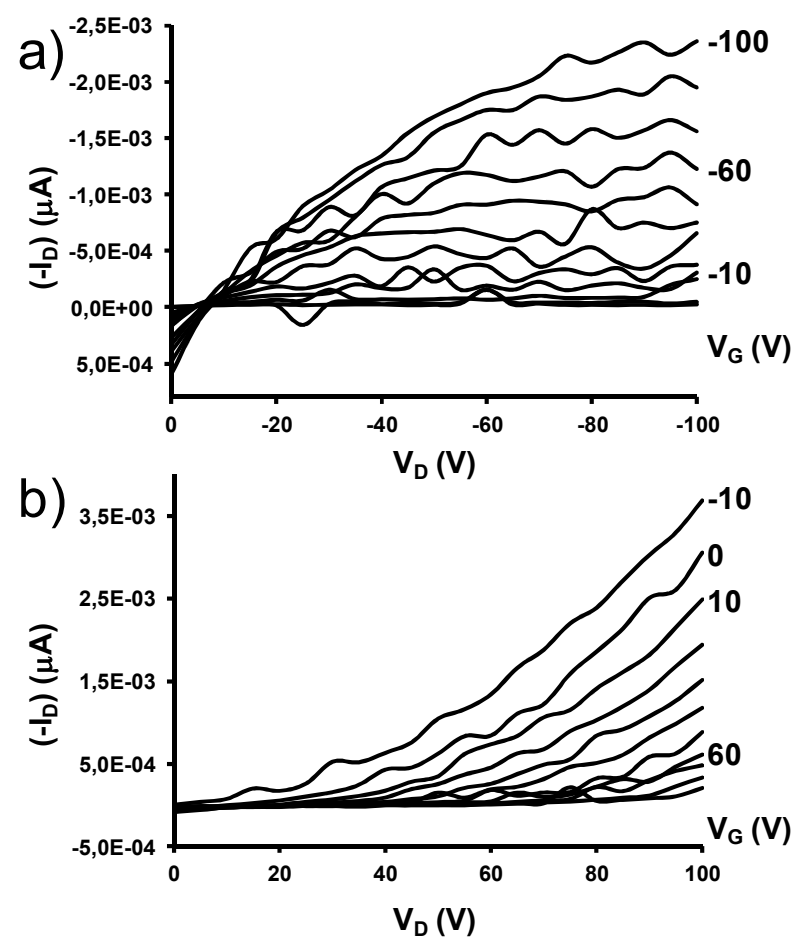

Fig. 3 Output characteristics of an OFET incorporating Cor1 under a) negative and b) positive voltages.

Table 1: Field effect mobilities ( $\mu$ ), threshold voltages (VT) and on/off ratio $\left(\mathrm{I}_{\mathrm{on}} / \mathrm{I}_{\text {off }}\right)$ of corrole-based OTFT devices.

\begin{tabular}{cccc}
\hline & $\mu\left(\mathrm{cm}^{2} \cdot \mathrm{V}^{-1} \cdot \mathrm{s}^{-1}\right)$ & $V_{\mathrm{T}}(\mathrm{V})$ & $I_{\text {on }} / I_{\text {off }}$ \\
\hline Cor1 & $1,36 \times 10^{-6}$ & $+14,8$ & 24,5 \\
Cor2 & $1,32 \times 10^{-7}$ & $+38,5$ & $\sim 10$ \\
\hline
\end{tabular}

\section{Conclusions}

We described herein the synthesis and full characterization of the first example of a corrole-based liquid crystal mesophase (CorLC). This mesophase features, at room temperature, an hexagonal columnar organization combined with an $\mathrm{H}$ arrangement of the discotic chromophores producing a blue shifted light absorption. This study shows that the introduction of numerous peripheral groups on copper corroles tunes their aggregation modes and their hole-transport properties. Since the copper ion can be removed using mild experimental conditions, ${ }^{22}$ CorLC can be used to prepare liquid crystal phases incorporating other metallic centers such as $\mathrm{Co}(\mathrm{III})^{11 \mathrm{a}}$ and $\mathrm{Mn}(\mathrm{III})^{14 \mathrm{a} a}$ that are already applied in the fields of sensors. 


\section{Experimental section}

\section{General Remarks}

All reagents were purchased from Acros, Alfa Aesar or Aldrich and were used without further purification unless otherwise stated. Toluene was distilled from sodium and benzophenone. Dichloromethane, hexane and $n$ heptane were distilled from calcium hydride. Dichloromethane stabilized by methanol was used during the preparation of OFETs. Silica gel plates Merck 60 F254 were used for Thin Layer Chromatography (TLC). Silica gel 60 (230-400 mesh) was used for preparative column chromatography. Flash column chromatography was performed on silica gel 60 (230-400 mesh). (3,5-bis(dodecyloxy)phenyl)methanol, ${ }^{23}$, Cor $^{15}$ and Cor2 ${ }^{16 a}$ were prepared and purified according to literature procedure.

\section{Spectroscopic and analytical measurements}

${ }^{1} \mathrm{H}$ Nuclear Magnetic Resonance (NMR) spectra were recorded on a Bruker Avance 400 Ultrashield NMR spectrometer. Chemical shifts are given in ppm relative to residual peaks of chloroform $(\delta=7.26 \mathrm{ppm})$, DMSO- $_{6}(\delta=2.50 \mathrm{ppm})$ or THF-d $8(\delta=1.73$ and $3.58 \mathrm{ppm})$.

UV/Vis absorption spectra were measured with a Shimadzu UV-2401 (PC) instrument or with a Varian Cary 1E spectrophotometer.

Pneumatically-assisted electrospray (ESI-MS) mass spectra were recorded from 10-4 M solutions on an Applied Biosystems API 150EX LC/MS System equipped with a Turbo lonspray source. High Resolution Mass Spectrometry (HRMS-ESI) analyses were performed on a QStar Elite (Applied Biosystems SCIEX) spectrometer or on a SYNAPT G2 HDMS (Waters) spectrometer. These two instruments are equipped with an electrospray ionization source and were used within the positive ion mode and with a capillary voltage set at $+5500 \mathrm{~V}$. MALDI-TOFF mass spectra were obtained on a Voyager Instrument from Applied Biosystems either with anhydrous glycerol, HABA [2'-(4-hydroxyphenylazo)benzoic acid], or 1,8,9-anthracenetriol (dithranol) matrices.

\section{Liquid crystals analyses.}

TGA was performed with a Seiko TG/DTA 320 thermogravimetric balance (under $\mathrm{N}_{2}$ ). DSC traces were recorded with a Mettler Toledo DSC1 Star Systems differential scanning calorimeter from 3 to $5 \mathrm{mg}$ samples $\left(5^{\circ} \mathrm{C}\right.$ $\mathrm{min}^{-1}$, under $\mathrm{N}_{2}$ ). Characterization of the mesophases was performed with a Leitz OrthoplanPol polarizing microscope with a Leitz LL 20x/0.40 polarizing objective and equipped with a Linkam THMS 600 variable temperature stage. The SA-XRD patterns were obtained with three different experimental setups, and in all cases, the crude powder was filled in Lindemann capillaries of $1 \mathrm{~mm}$ diameter. (1) A STOE STADI P transmission powder diffractometer system using a focused monochromatic $\mathrm{Cu}-\mathrm{Ka}_{1}$ beam obtained from a curved germanium monochromator (Johann-type) and collected on a curved image-plate position sensitive detector. A calibration with silicon and copper laurate standards, for high- and low-angle domains, respectively, was preliminarily performed. Sample capillaries were placed in the high-temperature attachment for measurements in the range of desired temperatures (from 20 to $160^{\circ} \mathrm{C}$ ), for which the sample temperature was controlled within 0.05 ${ }^{\circ} \mathrm{C}$. The exposure times were varied from 1 to $6 \mathrm{~h}$, depending on the specific reflections being sought (weaker reflections obviously taking longer exposure times).

\section{OFET preparations and studies}

Cor1, Cor2 and CorLC were dissolved in $\mathrm{CH}_{2} \mathrm{Cl}_{2}$ to a concentration of ca $5.10^{-3} \mathrm{M}$. The Bottom-Gate Bottom-Contact (BGBC) configuration was used for the OTFT devices. Highly n-doped silicon wafers (gate), covered with thermally grown silicon oxide $\mathrm{SiO}_{2}$ (3000 $\AA$, insulator layer), were purchased from Vegatec (France) and used as bottom-gate substrates The capacitance per unit area of silicon dioxide dielectric layers was $1.2 \times 10^{-8} \mathrm{~F} / \mathrm{cm}^{2}$. The gold (Au) source and drain electrodes (channel length $\mathrm{L}=25$ or $50 \mu \mathrm{m}$, channel width $\mathrm{W}=1 \mathrm{~mm}$ ) were evaporated directly on $\mathrm{SiO}_{2}$ layer prior the organic deposition through a shadow mask. Solutions of Cor1, Cor2 and CorLC (or pure liquid CorLC) were deposited by dropcasting to form the organic active layers in OTFT devices through a dropwise addition of 20-40 $\mu \mathrm{L}$ volumes onto the devices surfaces. Such volume covered entirely the channel of one OTFT and beyond. After the organic solution deposition, the devices were left overnight in ambient condition in order to remove residual solvent prior electrical measurements. A post-annealing step from 50 to $80^{\circ} \mathrm{C}$ was applied to all devices in order to increase the microstructural order of thin films. Currentvoltage characteristics were recorded at room temperature under ambient conditions with Hewlett-Packard 4140B, or 4145A, pico-amperemeter-DC voltage sources. The source-drain current (ID) in the saturation regime is governed by the equation (2):

\section{(2) $\left(I_{\mathrm{D}}\right)_{\mathrm{sat}}=(W / 2 L) C_{i} \mu\left(V_{G}-V_{t}\right)^{2}$}

$\mathrm{Ci}$ is the capacitance per unit area of the gate insulator layer, VG is the gate voltage, $\mathrm{Vt}$ is the threshold voltage, and $\mu$ is the field-effect mobility. The on/off ratio values were determined from the I-V transfer plots under a constant drain-source voltage VD $=-100 \mathrm{~V}$.

\section{Organic syntheses.}

Compound 1 : (3,5-bis(dodecyloxy)phenyl)methanol $(5.00 \mathrm{~g}, 10.5 \cdot \mathrm{mmol})$ was dissolved in dry $\mathrm{CH}_{2} \mathrm{Cl}_{2}(50 \mathrm{~mL})$ and DMF $(50 \mu \mathrm{l})$ was added under a nitrogen atmosphere. A solution of $\mathrm{SOCl}_{2}(1.87 \mathrm{~g}, 15.7 \cdot \mathrm{mmol})$ in dry $\mathrm{CH}_{2} \mathrm{Cl}_{2}(50 \mathrm{~mL})$ was added dropwise over a period of 1 hour. The reaction mixture was stirred at room temperature for 24 hours, evaporated to dryness and dried under vacuum to provide 1 as a white solid $(5.15 \mathrm{~g}, 10.4$ mmol, 99\%). 1H NMR (400 MHz, CDCl $): \delta=0.91\left(\mathrm{t},{ }^{3} J(\mathrm{H}, \mathrm{H})=6.6 \mathrm{~Hz}, 6 \mathrm{H}\right)$, 1.29-1.50 (m, 36H); 1.75-1.80 (m, 4H), $3.95\left(\mathrm{t},{ }^{3} J(\mathrm{H}, \mathrm{H})=6.5 \mathrm{~Hz}, 6 \mathrm{H}\right), 4.52$ $(\mathrm{s}, 2 \mathrm{H}), 6.42\left(\mathrm{t},{ }^{4} \mathrm{~J}(\mathrm{H}, \mathrm{H})=2.5 \mathrm{~Hz}, 1 \mathrm{H}\right), 6.53\left(\mathrm{~d},{ }^{4} \mathrm{~J}(\mathrm{H}, \mathrm{H})=2.5 \mathrm{~Hz}, 2 \mathrm{H}\right)$. ESIMS $\left(\mathrm{CH}_{2} \mathrm{Cl}_{2} / \mathrm{MeOH}\right.$ 9:1): m/z: $\left(\mathrm{M}+\right.$.): 495.5; calcd for $\mathrm{C}_{31} \mathrm{H}_{56} \mathrm{ClO}_{2}{ }^{+}: 495.4$.

Cu'llI undeca-(4-hydroxyphenyl)corrole: $\mathrm{A} 1 \mathrm{M}$ solution of $\mathrm{BBr}_{3}$ in $\mathrm{CH}_{2} \mathrm{Cl}_{2}$ $(10 \mathrm{~mL}, 10 \mathrm{mmol})$ was added to a solution of Cor2 $(45 \mathrm{mg}, 29.6 \mu \mathrm{mol})$ in $\mathrm{CH}_{2} \mathrm{Cl}_{2}(6 \mathrm{~mL})$ which was stirred at $0{ }^{\circ} \mathrm{C}$ for $15 \mathrm{~min}$. The mixture was kept at $0{ }^{\circ} \mathrm{C}$ for $1 \mathrm{~h}$ and then stirred at room temperature for 3 days before $\mathrm{CH}_{2} \mathrm{Cl}_{2}(20 \mathrm{~mL})$ and $\mathrm{CH}_{3} \mathrm{OH}(10 \mathrm{~mL})$ were added together with an aqueous saturated solution of $\mathrm{NaHCO}_{3}(35 \mathrm{~mL})$. The crude compound was precipitated by pouring the reaction mixture into water $(100 \mathrm{~mL})$. The precipitates were filtered and purified by chromatography on silica gel $\left(\mathrm{CH}_{2} \mathrm{Cl}_{2} / \mathrm{CH}_{3} \mathrm{OH}, 5: 1\right)$ to afford 3 as a brown powder (18 mg, $13.1 \mu \mathrm{mol}$, $44 \%) . \mathrm{R}_{f}=0.11\left(\mathrm{CH}_{2} \mathrm{Cl}_{2} / \mathrm{CH}_{3} \mathrm{OH}, 4: 1\right) .{ }^{1} \mathrm{H}$ NMR $\left(400 \mathrm{MHz}, \mathrm{THF}-d_{8}, 25^{\circ} \mathrm{C}\right)$ : $\delta=7.85(\mathrm{~s}, 2 \mathrm{H}, \mathrm{Ar}-\mathrm{OH}), 7.83(\mathrm{~s}, 3 \mathrm{H}, \mathrm{Ar}-\mathrm{OH}), 7.63(\mathrm{~s}, 2 \mathrm{H}, \mathrm{Ar}-\mathrm{OH}), 7.53(\mathrm{~s}$, $2 \mathrm{H}, \mathrm{Ar}-\mathrm{OH}), 7.47(\mathrm{~s}, 2 \mathrm{H}, \mathrm{Ar}-\mathrm{OH}), 6.94\left(\mathrm{~d},{ }^{3} \mathrm{~J}(\mathrm{H}, \mathrm{H})=8.4 \mathrm{~Hz}, 2 \mathrm{H}, \mathrm{Ar}-\mathrm{H}\right), 6.76$ $\left(\mathrm{d},{ }^{3} \mathrm{~J}(\mathrm{H}, \mathrm{H})=7.9 \mathrm{~Hz}, 4 \mathrm{H}, \mathrm{Ar}-\mathrm{H}\right), 6.66\left(\mathrm{~d},{ }^{3} \mathrm{~J}(\mathrm{H}, \mathrm{H})=8.4 \mathrm{~Hz}, 4 \mathrm{H}, \mathrm{Ar}-\mathrm{H}\right), 6.40$ $\left(\mathrm{d},{ }^{3} \mathrm{~J}(\mathrm{H}, \mathrm{H})=7.6 \mathrm{~Hz}, 8 \mathrm{H}, \mathrm{Ar}-\mathrm{H}\right), 6.40\left(\mathrm{~d},{ }^{3} \mathrm{~J}(\mathrm{H}, \mathrm{H})=8.0 \mathrm{~Hz}, 4 \mathrm{H}, \mathrm{Ar}-\mathrm{H}\right), 6.27$ $\left(\mathrm{d},{ }^{3} \mathrm{~J}(\mathrm{H}, \mathrm{H})=8.5 \mathrm{~Hz}, 4 \mathrm{H}, \mathrm{Ar}-\mathrm{H}\right), 6.09(\mathrm{~m}, 8 \mathrm{H}, \mathrm{Ar}-\mathrm{H}), 6.03\left(\mathrm{~d},{ }^{3} \mathrm{~J}(\mathrm{H}, \mathrm{H})=8.6\right.$ $\mathrm{Hz}, 4 \mathrm{H}, \mathrm{Ar}-\mathrm{H}), 5.96\left(\mathrm{~d},{ }^{3} \mathrm{~J}(\mathrm{H}, \mathrm{H})=7.5 \mathrm{~Hz}, 4 \mathrm{H}, \mathrm{Ar}-\mathrm{H}\right), 5.93 \mathrm{ppm}\left(\mathrm{d},{ }^{3} \mathrm{~J}(\mathrm{H}, \mathrm{H})\right.$ $=8.5 \mathrm{~Hz}, 2 \mathrm{H}, \mathrm{Ar}-\mathrm{H})$. UV-Vis (THF): $\lambda_{\max }\left(\varepsilon \times 10^{-3}\right)=468$ (83.6), 550 (18.7), $643 \mathrm{~nm}$ (12.2). MALDI-TOF $\left(\mathrm{M}^{+}\right)$: 1370.2 ; calcd for $\mathrm{C}_{85} \mathrm{H}_{55} \mathrm{CuN}_{4} \mathrm{O}_{11}{ }^{+}$: 1370.3 .

CorLC : Cull undeca-(4-hydroxyphenyl)corrole (7.2 $\mu \mathrm{mol}, 10 \mathrm{mg})$, compound 1 (22 equiv., $79.2 \mu \mathrm{mol}, 39 \mathrm{mg}$ ) and $\mathrm{K}_{2} \mathrm{CO}_{3}$ (44 equiv., 158.4 $\mu \mathrm{mol}, 22 \mathrm{mg}$ ) were added to a round-bottomed flask which was oven dried overnight at $111^{\circ} \mathrm{C}$. The flask was evacuated and backfilled with argon three consecutive times. Dry DMF $(5 \mathrm{~mL})$ was then charged by a syringe. The mixture was subsequently stirred at $90^{\circ} \mathrm{C}$ for $24 \mathrm{~h}$. After being cooled to room temperature, the solvent was evaporated under reduced pressure. The crude product was purified by chromatography on silica gel 
$\left(\mathrm{CH}_{2} \mathrm{Cl}_{2} /\right.$ heptane, $\left.2: 1\right)$ to yield CorLC as a viscous oil $(11 \mathrm{mg}, 1.6 \mu \mathrm{mol}$, 23\%). $\mathrm{R}_{f}=0.64\left(\mathrm{CH}_{2} \mathrm{Cl}_{2} / \mathrm{Hexane}, 2: 1\right) .{ }^{1} \mathrm{H} \mathrm{NMR}\left(400 \mathrm{MHz}, \mathrm{CDCl}_{3}, 25{ }^{\circ} \mathrm{C}\right)$ $\delta=6.97\left(\mathrm{~d},{ }^{3} \mathrm{~J}(\mathrm{H}, \mathrm{H})=8.6 \mathrm{~Hz}, 3 \mathrm{H}, \mathrm{Ar}-\mathrm{H}\right), 6.83(\mathrm{t}, 8 \mathrm{H}, \mathrm{Ar}-\mathrm{H}), 6.61$ (brs, $4 \mathrm{H}$, $\mathrm{Ar}-\mathrm{H}), 6.51\left(\mathrm{~d},{ }^{3} \mathrm{~J}(\mathrm{H}, \mathrm{H})=8.6 \mathrm{~Hz}, 4 \mathrm{H}, \mathrm{Ar}-\mathrm{H}\right), 6.47(\mathrm{~m}, 13 \mathrm{H}, \mathrm{Ar}-\mathrm{H}), 6.42(\mathrm{t}$, $8 \mathrm{H}, \mathrm{Ar}-\mathrm{H}), 6.38(\mathrm{~m}, 4 \mathrm{H}, \mathrm{Ar}-\mathrm{H}), 6.35(\mathrm{~m}, 10 \mathrm{H}, \mathrm{Ar}-\mathrm{H}), 6.35(\mathrm{~m}, 13 \mathrm{H}, \mathrm{Ar}-\mathrm{H})$, $6.27\left(\mathrm{~d},{ }^{3} \mathrm{~J}(\mathrm{H}, \mathrm{H})=8.8 \mathrm{~Hz}, 4 \mathrm{H}, \mathrm{Ar}-\mathrm{H}\right), 6.17\left(\mathrm{~d},{ }^{3} \mathrm{~J}(\mathrm{H}, \mathrm{H})=7.5 \mathrm{~Hz}, 4 \mathrm{H}, \mathrm{Ar}-\mathrm{H}\right)$, $6.12\left(\mathrm{~d},{ }^{3} \mathrm{~J}(\mathrm{H}, \mathrm{H})=8.7 \mathrm{~Hz}, 2 \mathrm{H}, \mathrm{Ar}-\mathrm{H}\right), 4.80\left(\mathrm{~s}, 4 \mathrm{H}, \operatorname{ArOCH}_{2} \mathrm{Ar}\right), 4.72(\mathrm{~s}, 4 \mathrm{H}$, $\mathrm{ArOCH}_{2} \mathrm{Ar}$ ), 4.70 (s, 4H, ArOCH $\mathrm{H}_{2} \mathrm{Ar}$ ), 4.68 (s, 4H, ArOCH $\mathrm{H}_{2} \mathrm{Ar}$ ), 4.64 (d, 6H, ArOCH $\left.H_{2} \mathrm{Ar}\right), 3.80\left(\mathrm{~m}, 44 \mathrm{H}, \mathrm{OCH}_{2} \mathrm{CH}_{2}\right), 1.68\left(\mathrm{~m}, 44 \mathrm{H}, \mathrm{OCH}_{2} \mathrm{CH}_{2}\right), 1.38(\mathrm{~m}$ $\left.44 \mathrm{H}, \mathrm{OCH}_{2} \mathrm{CH}_{2} \mathrm{CH}_{2}\right), 1.25(\mathrm{~m}, 352 \mathrm{H}), 0.86 \mathrm{ppm}\left(\mathrm{m}, 66 \mathrm{H}, \mathrm{CH}_{3}\right)$. UV-Vis $\left(\mathrm{CH}_{2} \mathrm{Cl}_{2}\right): \lambda_{\max }\left(\varepsilon \times 10^{-3}\right)=464$ (124.3), 549 (29.4), $639 \mathrm{~nm}$ (17.4). MALDITOF $\left(\mathrm{M}^{+}\right)$: 6417.5 (Maximum iso); calcd for $\mathrm{C}_{426} \mathrm{H}_{649} \mathrm{CuN}_{4} \mathrm{O}_{33}{ }^{+}: 6417.9$ (Maximum iso); ([M+Na] $]^{+}$): 6440.4 ; calcd for $\mathrm{C}_{426} \mathrm{H}_{649} \mathrm{CuN}_{4} \mathrm{O}_{33} \mathrm{Na}^{+}: 6440.9$.

\section{Acknowledgements}

Dr. Laure Guénée is acknowledged for SA-XRD measurements. Dr. Di Gao gratefully thanks the China Scholarship Council for granting him his PHD fellowship in Marseille.

\section{Notes and references}

a Aix Marseille Université, Centrale Marseille, CNRS, iSm2 UMR 7313, 13397, Marseille, France.

${ }^{b}$ Aix Marseille Université, CNRS, CINaM UMR 7325, 13288, Marseille, France. Fax: (+33) 49141 8916; E-mails: gabriel.canard@univ-amu.fr and videlot@cinam.univ-mrs.fr

${ }^{c}$ Department of Inorganic and Analytical Chemistry, University of Geneva, 30 quai Ernest-Ansermet, CH-1211Geneva 4, Switzerland. Fax: (+41) 022 37960 69; E-mail: emmanuel.terazzi@unige.ch

1 (a) A. R. Murphy and J. M. J. Frechet, Chem. Rev., 2007, 107, 1066; (b) J.-H. Chou, M. E. Kosal, H. S. Nalwa, N. A. Rakow and K. S Suslick, in The Porphyrin Handbook, eds. K. M. Kadish, K. M. Smith and R. Guilard, Academic Press, New York, 2000, vol. 6, pp 43; (c) M. Bouvet, Anal. Bioanal. Chem., 2006, 384, 366.

2 (a) H. Imahori, T. Umeyama, K. Kurotobi and Y. Takano, Chem. Commun., 2012, 48, 4032; (b) J. Kesters, P. Verstappen, M. Kelchtermans, L. Lutsen, D. Vanderzande and W. Maes, Adv. Energy Mater., 2015, 5, 1500218 .

3 K. Y. Law, Chem. Rev., 1993, 93, 449.

4 (a) K. Ohta, H.-D. Nguyen-Tran, L. Tauchi, Y. Kanai, T. Megumi and Y. Takagi, in Handbook of Porphyrin Science, eds. K. M. Kadish, K. M. Smith and R. Guilard, 2011, vol. 12, pp. 1; (b) A Segade, F. López-Calahorra and D. Velasco, J. Phys. Chem. B, 2008, 112, 7395 .

5 H. Eichhorn, J. Porphyrins Phthalocyanines, 2000, 4, 88.

6 A. Huijser, T. J. Savenije, A. Kotlewski, S. J. Picken and L. D. A. Siebbeles, Adv. Mater., 2006, 18, 2234.

7 N. B. Chaure, C. Pal, S. Barard, T. Kreouzis, A. K. Ray, A. N. Cammidge, I. Chambrier, M. J. Cook, C. E. Murphy and M. G. Cain, J. Mater. Chem., 2012, 22, 19179.

8 (a) D. T. Gryko, Eur. J. Org. Chem., 2002, 1735; (b) S. Nardis, D Monti and R. Paolesse, Mini-Rev. Org. Chem., 2005, 2, 355; (c) B. Koszarna and D. T. Gryko, J. Org. Chem., 2006, 71, 3707; (d) D. T Gryko, J. Porphyrins Phthalocyanines, 2008, 12, 906; (e) R. Paolesse, Synlett, 2008, 2215.

9 (a) J. F. B. Barata, M. G. P. M. S. Neves, A. C. Tomè and J. A. S Cavaleiro, J. Porphyrins Phthalocyanines, 2009, 13, 415; (b) C. M.
Lemon and P. J. Brothers, J. Porphyrins Phthalocyanines, 2011, 15, 809; (c) C. I. M. Santos, J. F. B. Barata, M. J. F. Calvete, L. S. H. P. Vale, D. Dini, M. Meneghetti, M. G. P. M. S. Neves, M. A. F. Faustino, A. C. Tomé and J. A. S. Cavaleiro, Curr. Org. Synth., 2014, 11, 29.

10 (a) J. P. Collman, M. Kaplun and R. A. Decréau, Dalton Trans., 2006, 554; (b) I. Aviv and Z. Gross, Chem. Commun., 2007, 1987; (c) I. Aviv-Harel and Z. Gross, Chem. Eur. J., 2009, 15, 8382; (d) I. Nigel-Etinger, A. Mahammed and Z. Gross, Catal. Sci. Technol., 2011, 1, 578; (e) H.-Y. Liu, M. H. R. Mahmood, S.-X. Qiu and C. K. Chang, Coord. Chem. Rev., 2013, 257, 1306; (f) K. Nakano, K. Kobayashi, T. Ohkawara, H. Imoto and K. Nozaki, J. Am. Chem. Soc., 2013, 135, 8456; ( $g$ ) B. Zyska and M. Schwalbe, Chem. Commun., 2013, 49, 3799; (h) S. Liu, K. Mase, C. Bougher, S. D. Hicks, M. M. Abu-Omar and S. Fukuzumi, Inorg. Chem., 2014, 53, 7780 .

11 (a) J.-M. Barbe, G. Canard, S. Brandès and R. Guilard, Angew. Chem. Int. Ed., 2005, 44, 3103; (b) C.-Y. Li, X.-B. Zhang, Z.-X. Han, B. Aakermark, L. Sun, G.-L. Shen and R.-Q. Yu, Analyst, 2006, 131, 388; (c) K. Kurzatkowska, E. Dolusic, W. Dehaen, K. Sieroń-Stołtny, A. Sieroń and H. Radecka, Anal. Chem., 2009, 81, 7397; (d) V. Blondeau-Patissier, M. Vanotti, T. Prêtre, D. Rabus, L. Tortora, J. M. Barbe and S. Ballandras, Procedia Eng., 2011, 25, 1085; (e) S. Yang, Y. Wo and M. E. Meyerhoff, Anal. Chim. Acta, 2014, 843, 89.

12 (a) Z. Okun, L. Kupershmidt, M. B. H. Youdim and Z. Gross, AntiCancer Agents Med. Chem., 2011, 11, 380; (b) J. Pohl, I. Saltsman, A. Mahammed, Z. Gross and B. Röder, J. Appl. Microbiol., 2014, 118, 305; (c) R. D. Teo, H. B. Gray, P. Lim, J. Termini, E. Domeshek and Z. Gross, Chem. Commun., 2014, 50, 13789; (d) J. F. B. Barata, A. Zamarrón, M. G. P. M. S. Neves, M. A. F. Faustino, A. C. Tomé, J. A. S. Cavaleiro, B. Röder, Á. Juarranz and F. Sanz-Rodríguez, Eur. J. Med. Chem., 2015, 92, 135.

13 (a) M. Stefanelli, D. Monti, M. Venanzi and R. Paolesse, New J. Chem., 2007, 31, 1722; (b) A. P. Caricato, M. Lomascolo, A. Luches, F. Mandoj, M. G. Manera, M. Mastroianni, M. Martino, R. Paolesse, R. Rella, F. Romano, T. Tunno and D. Valerini, Appl. Phys. A, 2008, 93, 651; (c) X. Miao, A. Gao, Z. Li, S. Hiroto, H. Shinokubo, A. Osuka and W. Deng, Appl. Surf. Sci., 2009, 255, 5885; (d) R. van Hameren, J. A. A. W. Elemans, D. Wyrostek, M. Tasior, D. T. Gryko, A. E. Rowan and R. J. M. Nolte, J. Mater. Chem., 2009, 19, 66; (e) T. Hori and A. Osuka, Eur. J. Org. Chem., 2010, 2379; (f) M. Ding, B. Wang, Z. Wang, J. Zhang, O. Fuhr, D. Fenske and S. Gao, Chem. Eur. J., 2012, 18, 915; (g) J. F. B. Barata, A. L. Daniel-daSilva, M. G. P. M. S. Neves, J. A. S. Cavaleiro and T. Trindade, $R S C$ $A d v ., 2013,3$, 274; (h) C. I. M. Santos, E. Oliveira, J. FernándezLodeiro, J. F. B. Barata, S. M. Santos, M. A. F. Faustino, J. A. S. Cavaleiro, M. G. P. M. S. Neves and C. Lodeiro, Inorg. Chem., 2013, 52, 8564; (i) B. Bursa, D. Wróbel, K. Lewandowska, A. Graja, M. Grzybowski and D. T. Gryko, Synth. Met., 2013, 176, 18; (j) A. D'Urso, S. Nardis, G. Pomarico, M. E. Fragalà, R. Paolesse and R. Purrello, J. Am. Chem. Soc., 2013, 135, 8632; (k) C. M. Blumenfeld, B. F. Sadtler, G. E. Fernandez, L. Dara, C. Nguyen, F. AlonsoValenteen, L. Medina-Kauwe, R. A. Moats, N. S. Lewis, R. H. Grubbs, H. B. Gray and K. Sorasaenee, J. Inorg. Biochem., 2014, 140, 39; ( $l$ ) I. Grabowska, W. Maes, T. H. Ngo, T. Rohand, W. Dehaen, J. Radecki and H. Radecka, Int. J. Electrochem. Sci., 2014, 
9, 1232; (m) A. Garai, S. Kumar, W. Sinha, C. S. Purohit, R. Das and S. Kar, RSC Adv., 2015, 5, 28643; (n) R. Orłowski, O. Vakuliuk, M. P. Gullo, O. Danylyuk, B. Ventura, B. Koszarna, A. Tarnowska, N. Jaworska, A. Barbieri and D. T. Gryko, Chem. Commun., 2015, 51, 8284.

14 (a) R. Paolesse, C. Di Natale, A. Macagnano, F. Sagone, M. A. Scarselli, P. Chiaradia, V. I. Troitsky, T. S. Berzina and A. D'Amico, Langmuir, 1999, 15, 1268; (b) D. Walker, S. Chappel, A. Mahammed, B. S. Brunschwig, J. R. Winkler, H. B. Gray, A. Zaban and Z. Gross, J. Porphyrins Phthalocyanines, 2006, 10, 1259; (c) W. Nulens, I. Grabowska, T. H. Ngo, W. Maes, W. Dehaen, H. Radecka and J. Radecki, J. Inclusion Phenom. Macrocyclic Chem., 2011, 71, 499; (d) L. Tortora, G. Pomarico, S. Nardis, E. Martinelli, A. Catini, A. D'Amico, C. Di Natale and R. Paolesse, Sens. Actuators B: Chem., 2013, 187, 72; (e) W. Sinha, M. Kumar, A. Garai, C. S. Purohit, T. Som and S. Kar, Dalton Trans., 2014, 43, 12564; (f) S.-L. Lai, L. Wang, C. Yang, M.-Y. Chan, X. Guan, C.-C. Kwok and C.-M. Che, Adv. Funct. Mater., 2014, 24, 4655; (g) P. Salvatori, A. Amat, M. Pastore, G. Vitillaro, K. Sudhakar, L. Giribabu, Y. Soujanya and F. De Angelis, Comput. Theor. Chem., 2014, 1030, 59; (h) S. Hamad, G. Krishna Podagatlapalli, M. Ahamad Mohiddon and S. Venugopal Rao, Chem. Phys. Lett., 2015, 621, 171.

15 I. H. Wasbotten, T. Wondimagegn and A. Ghosh, J. Am. Chem. Soc., 2002, 124, 8104.

16 (a) D. Gao, G. Canard, M. Giorgi and T. S. Balaban, Eur. J. Inorg. Chem., 2012, 5915; (b) D. Gao, G. Canard, M. Giorgi, P. Vanloot and T. S. Balaban, Eur. J. Inorg. Chem., 2014, 2014, 279.

17 (a) B. Donnio, B. Heinrich, T. Gulik-Krzywicki, H. Delacroix, D. Guillon and D. W. Bruce, Chem. Mater., 1997, 9, 2951; (b) B. Donnio, D. W. Bruce, H. Delacroix and T. Gulik-Krzywicki, Liq. Cryst., 1997, 23, 147; (c) B. Donnio, K. E. Rowe, C. P. Roll and D. W. Bruce, Mol. Cryst. Liq. Crys. A, 1999, 332, 2893; (d) E. Terazzi, S. Torelli, G. Bernardinelli, J.-P. Rivera, J.-M. Bénech, C. Bourgogne, B. Donnio, D. Guillon, D. Imbert, J.-C. G. Bünzli, A. Pinto, D. Jeannerat and C. Piguet, J. Am. Chem. Soc., 2005, 127, 888.

18 A. Alemayehu, J. Conradie and A. Ghosh, Eur. J. Inorg. Chem., 2011, 1857.

19 S. Berg, K. E. Thomas, C. M. Beavers and A. Ghosh, Inorg. Chem., 2012, 51, 9911.

20 (a) C. Brückner, R. P. Briñas and J. A. Krause-Bauer, Inorg. Chem., 2003, 42, 4495; (b) I. Luobeznova, L. Simkhovich, I. Goldberg and Z. Gross, Eur. J. Inorg. Chem., 2004, 1724; (c) A. B. Alemayehu, E. Gonzalez, L. K. Hansen and A. Ghosh, Inorg. Chem., 2009, 48, 7794; (d) D. Bhattacharya, P. Singh and S. Sarkar, Inorg. Chim. Acta, 2010, 363, 4313; (e) A. B. Alemayehu, L. K. Hansen and A. Ghosh, Inorg. Chem., 2010, 49, 7608.

21 S. Sergeyev, W. Pisula and Y. H. Geerts, Chem. Soc. Rev., 2007, 36, 1902.

22 (a) F. Mandoj, S. Nardis, G. Pomarico and R. Paolesse, J. Porphyrins Phthalocyanines, 2008, 12, 19; (b) C. Capar, K. E. Thomas and A. Ghosh, J. Porphyrins Phthalocyanines, 2008, 12, 964; (c) T. H. Ngo, W. Van Rossom, W. Dehaen and W. Maes, Org. Biomol. Chem., 2009, 7, 439.

23 B. Donnio, P. García-Vázquez, J.-L. Gallani, D. Guillon, E. Terazzi, Adv. Mater., $\quad$ 2007, $\quad 19, \quad 3534$. 